\author{
Mykola Dyomin \\ ๑ https://orcid.org/0000-0001-6758-3851 \\ Kyiv National University of Construction and Architecture \\ yulia-ivashko@ukr.net
}

Oleksandr Ivashko

- $h$ ttps://orcid.org/0000-0002-9194-2153

Kyiv National University of Construction and Architecture

ghok2233@gmail.com

\title{
STREET ART: AN ARTISTIC MESSAGE IN THE MODERN URBAN ENVIRONMENT
}

\begin{abstract}
Throughout the existence of humankind, at different periods, relevant criteria have been formed for informative means and the subject matter of works of art. The twentieth century was characterised by a fundamental reinterpretation of the meaningfulness and informationbearing message of art, which had lost its dominance of basic informational values - conveying aesthetic ideals, education of society in the spirit of harmony and beauty, introducing moral qualities with the use of artistic means, ideological orientation, etc. In stark contrast to traditional art and to centuries-old artistic means of delivering certain information was street art, and the root cause of its emergence were the social problems of the post-war period in poor New York neighbourhoods. Growing in the reality of unemployment, general depression and poverty, children invented new forms of entertainment using whatever they could find around. And then, some years later, these new forms instantly reached almost all the countries of the world - both poor and rich. Yes, those post-war years brought skateboards, rap, graffiti and street art in the forms in which we know them today. Gradually, the meaningfulness of street art greatly deepened and expanded. In addition to self-expression and social protest, the list of topics also started to include an individual's protest against total globalization. Political implications also appeared. For example, they are definitely characteristic for the graffiti and murals of the Revolution of Dignity in Ukraine. In the process of its development, legal street art was separated from illegal, purely amateur, spontaneous street art and artists who started "commercial street art" appeared, even though it would be more correct to call it urban art or simply modern art, since it is no longer created in street conditions, but is rather increasingly becoming the prerogative of art galleries and private customers. The attitude of other artists who do not consider their work for commerce is often somewhat ambiguous, as they promote art outside politics and commerce,
\end{abstract}


i.e. "art for art's sake". A similar phenomenon concerned street art which originated in parallel with it. However, it was also determined by the needs of the creative development of young artists without available financing, became an art cluster, or rather a creative cluster which emerged due to the availability of a significant number of unused industrial enterprises where empty rooms were rented by artists for a token fee.

The peculiarity of street art is its self-sufficiency, as its main narrative is intervention in urban space. In this case, the purpose of the narration of each artist is different: a particular message to leave a memory, a reaction to a political event, a form of protest, creative inspiration, etc. When street art evolves from spontaneous acts of art to an exhibit at a festival or gallery space, it can acquire a trans-media character, complemented by dances, performances or music.

Keywords: street art, graffiti, muralism, criteria for the evaluation of art, information content, meaningfulness.

\section{Introduction}

Challenges of the time have prompted modern society to radically revise the information message which is conveyed by works of art, as well as the artistic means and methods of delivering this message.

The problems that society has faced from the first decades of the twentieth century caused a sharp departure from the aesthetics of art to anti-aesthetics ${ }^{1}$. This departure had begun even earlier in a hidden form, in the secession period. A lot of images of terrible fantastic creatures and horror-stricken people, and the theme of wickedness and evil as such, were introduced at that time. Gradually, art lost its principal function - aesthetic education through the introduction of harmonious ideals. Instead of it, replacing aestheticisation, antiaesthetics or "aesthetics of the disgusting" emerged. It can be argued that the purpose of art was revised in the twentieth century and art theories developed in the previous centuries were discarded, since phenomena that did not earlier refer to art began to be attributed to it. One of the most controversial creative movements, whose attribution to art is still being debated by scientists, is street art along with the subculture of graffiti. Both have spread in most countries of the world and have caused a reaction of controversy in the general public. These two varieties of street art are quite identical and it is often impossible to find out exactly where graffiti ends and street art begins. The demarcation is rather relative, especially considering the fact that graffiti is frequently a component of street art, often a separate phenomenon that gives rise to street art and sometimes both. In the first part of this article, we will consider the two as a homologous unity, as two integral parts of one whole, continually moving from one to another, i.e. graffiti as part of street art and, at the same time, as an

1 Ortodox Poltavshchyna (composed by A. Dmytrenko, L. Onischuk, V. Shulyk), ASMI, Poltava 2008. 
individual type of art. So, when we mention the characteristics of street art, it will be true for graffiti and vice versa. Sociologists and psychologists consider them to be a kind of a protest reaction of an individual to globalism with its challenges and to deepening crisis phenomena. They become an expression of an artist's personality. Young people approve of or remain neutral towards graffiti on the city streets, while representatives of the older generation consider graffiti as a manifestation of vandalism and postulate the need to completely remove it from cities. However, it proves impossible to get rid of graffiti, since deepening social problems, globalization and complete absence of places suitable for drawing in all the cities of Ukraine encourage artists to paint anywhere. In European countries, particularly in Poland, city authorities allocate specific places for drawing, which has somewhat freed historical districts from graffiti, but has not prevented people from spreading paintings on the walls of buildings.

Another proof that graffiti has acquired some characteristics of an artistic movement is the fact that many international festivals that bring together hundreds of artists from around the world have been organized, visual materials have been actively distributed through social networks and collaboration with well-known brands has taken place. However, if you look progressively, street art has long penetrated many areas of life and has become an integral part of the $21^{\text {st }}$ century.

Graffiti, which arose primarily as a protest against the social problems of poor neighbourhoods, and then turned into a competition for writing one's nickname, has gradually lost its course. It is often just an artistic execution of inscription or writing with a subject image, where the "author's style" (the individualism of the invented font), originality of the plot and skill of execution are evaluated. Given the negative attitude towards plagiarism and the appreciation of the authenticity of style, we can assume that this kind of activity has gradually acquired some traits of art, although it is unconventional and based on completely different aesthetic categories, as compared to the art of the past centuries and millennia. However, it should be emphasised that even within the framework of the so-called traditional art, the notion of "tradition" is slightly subjective, considering what this concept indicated in various periods and what artistic means were used. From this point of view, street art and graffiti are no further from traditional art than the art of Ancient Egypt from the art of the Rococo era in France, taking into account the information delivered by these works and the ways of conveying the information. How can we deny street art the right to be acknowledged as modern art, only because it utilises fundamentally different means of artistic expression and other equipment (aerosol cans), if it is impossible to evaluate the art of the baroque, rococo or Secession with the use of the artistic canons of, let us say, Ancient Egypt? Paulina Szta- 
bińska-Kałowska notes that "cultural turns began to appear in the seventies of the twentieth century, opening up invisible fields of research and changing the approach to most cultural phenomena. Thus, the theoretical and methodological canon established by tradition was violated". ${ }^{2}$ It led both to a change in the criteria for evaluating works of art, as well as in the ratio between the types of art. Paulina Sztabińska-Kałowska presents an analysis of these phenomena in contemporary art: "The performative turn is characterized by the fact that some theoretical and methodological postulates that were previously applied to the performing arts (theatre, scenic art, etc.), now relate to the areas that were previously opposed to them or at least characterized in different ways (e.g. architecture, painting or sculpture)". ${ }^{3}$

Thus, here we approach the problem of criteria for evaluating street art, taking into account its specificity.

In our opinion, it is reasonable to evaluate street art with reference to the performance skill and not to the connection with the aesthetic categories of previous centuries.

Street art can be categorised as art, if we consider art as a type of human activity, a form of research and a reflection on reality through artistic images, thus characterizing art as a specific form of human consciousness and a sphere of spiritual production (similar to industrial production) which requires qualified specialists. If we put the equals sign between the terms "art" and "mastery", it immediately gives us an argument to classify skilfully executed street artworks as art. ${ }^{4}$ We particularly emphasise that objective evaluation should take place only based on the indicators of artistic mastery that were developed within the limits of street art, since all artworks should be compared and evaluated according to a unified system of indicators.

Therefore, the issue of aesthetic evaluation of street art and of the value of information delivered by it to society is directly related to the broader concept of "art" in terms of a specific form of social consciousness and the criteria for attributing some phenomena to art. Some researchers pointed out the direct dependence between the process of recognizing a phenomenon as art and works of art which provide criteria for evaluation, while appreciating its limitations and even the impossibility of evaluating art according to the criteria used in other epochs. It turned out that the artistic perfection of an artwork is determined primarily by its continuity with the established traditions, which automatically deprived avantgarde works of the opportunity to become works of art.

\footnotetext{
P. Sztabińska-Kałowska, Sztuka w świetle zwrotu performatywnego, manuscript, pp. 1-3. Ibidem.

4 G. Sztabiński, Why Do We Need the Term "Art"?, "Art Inquiry. References sur les arts” 2019 vol. XXI (XXX), pp.19-35.
} 
In the process of development, graffiti has become much more sophisticated. This is evident when the style, colours and plots of modern graffiti are compared with the ones of the past decades. Materials and methods of applying images have been improved and graffiti now has mass character. It is easy to execute and one does not need to obtain professional training at universities to perform it. The initial form of protest of youth subcultures has gradually become a means of transforming and modernising the contemporary architectural environment. As a result, skilfully executed street art has certainly risen to the rank of contemporary art.

The first theories which practically granted graffiti the status of full-fledged contemporary avant-garde art, especially relevant as a means of visual agitation, appeared in 1961, and, since the 1990s, graffiti has acquired the role of political propaganda.

Another phenomenon which is mentioned in parallel with graffiti in the literature, the art cluster, was associated with street art. ${ }^{5}$ An art cluster is not a type of an architectural building similar to a museum or an exhibition centre, but, above all, it is a specific form of organising internal space based on the existing system of internal relations between participants. The concept of the art cluster emerged due to the same reasons as street art did, which is confirmed by similar geography and chronology of the emergence and development. Just as street art was aimed at expressing the individuality of a financially insecure artist without dogma and restrictions, the art cluster allowed for the creative unification of young, financially insecure artists without reference to established norms and dogmas of artistic creation. The walls of houses became the canvas for street art artists deprived of the opportunity to buy expensive supplies, while the buildings of abandoned industrial enterprises, where for a symbolic fee you could rent a room and equip it yourself, were the place of creative expression for young artists who could not afford to rent expensive workshops.

Despite the rather wide use of the term "art cluster", concerning perhaps most revitalised industrial enterprises including exhibition space or an art store, an analysis of how they function shows that they often do not have a peculiar art component or cluster, but represent a rough group of random tenants, some of whom are engaged in creative activities.

5 O. Ivashko, The issues of conservation and revitalization of the monuments of industrial architecture. "Wiadomości Konserwatorskie - Journal of Heritage Conservation" 2019/58, pp. 113-117; P. Kulikov, M. Dyomin, D. Chernyshev, D. Kuśnierz-Krupa, M. Krupa, The issues of preservation and revitalization of residential, public and industrial buildings from the second half of the 19th and early 20th centuries in Kyiv and Krakow, "Wiadomości Konserwatorskie - Journal of Heritage Conservation” 2019/60, pp. 140-146. 


\section{Means of conveying information and street art techniques}

As a source base, we used art publications by S. Bezklubenko, ${ }^{6}$ Yu. Ivashko, O. Shylo, O. Petrova, Grzegorz Sztabiński ${ }^{7}$ and Paulina Sztabińska-Kałow$\mathrm{ska}^{8}$ which raise the issues of criteria for artistic evaluation, the relationship between art and power that directly relates to street art with its clear division into legal and illegal art (vandalism), ${ }^{9}$ the Secession roots of modern art, ${ }^{10}$ the continuity of street art with monumental art, ${ }^{11}$ and cultural issues concerning modern Ukrainian art and its assessment. ${ }^{12}$

The informativeness of street art can be traced on the basis of such phenomena as graffiti, muralism, street dancing, music, performances or installations, since each of them uses some means of conveying information. Moreover, several types of art are often combined into one expressive form - dancing against the background of painted walls, a simultaneous combination of dancing and a particular stage performance, etc. Graffiti or murals painted on walls often become artistic decorations for a particular television or film story. Moreover, even in modern architecture, there are signs of performance, as Paulina Sztabińska-Kałowska emphasises. ${ }^{13}$

6 S. Bezklubenko, Essays on the general theory of art. I. What is art?, "Bulletin of KNUKIM". "Series in Arts" 2000/ 3, pp. 4-19; S. Bezklubenko, Essays on the general theory of art. II. The origin of art, "Bulletin of KNUKIM". "Series in Arts", 2001/4, pp. 4-33; S. Bezklubenko, Essays on the general theory of art III. The formation of art form. What is "artistic", "Bulletin of KNUKIM". "Series in Arts” 2001/6, pp. 16-26; S. Bezklubenko, Essays on the general theory of art. V. Formation of the arts. Ch. I. Applied art; Ch. II. Building art, "Bulletin of KNUKIM". "Series in Arts" 2002/7, pp. 10-20; S. Bezklubenko, Essays on the general theory of art. Culture and art in the modern world: scientific issues, "Bulletin of KNUKIM", 2002/7, pp. 164-168; S. Bezklubenko, Essays on the general theory of art. VI. The formation of the arts. Chapter 3. Painting; Chapter 4. Musical art, "Bulletin of KNUKIM". "Series in Arts", 2003/8, pp. 12-29.

7 G. Sztabiński, op. cit.

8 P. Sztabińska-Kałowska, How does performance affect the understanding of 'Art'. "Art Inquiry. References sur les arts” 2019 volume XXI (XXX), pp. 111-127.

9 S. Bezklubenko, Art and power. Grumpy spouses?, "Viche" 1997/ 8, pp. 125-134.

10 Yu. Ivashko, Features of the use of natural motifs in modern architecture. "Bulletin of Lviv Polytechnic National University" 2009/656, pp. 38-43; Yu. Ivashko, The influence of Japanese art on the art and architecture of Europe in the late nineteenth and early twentieth centuries, "Linguistic and Conceptual Views of the World" 2010, vol. 28, pp. 250-254; Yu. Ivashko, T. Kuzmenko, S. Li, P. Chang, The influence of the natural environment on the transformation of architectural style, "Landscape architecture and Art" 2019, vol. 8, No 8, pp. 101-108.

11 O. Shylo, O. Ivashko, Monumental art and street art in modern urban space "Scientific Herald of Construction”, 2016/2 (84), pp. 74-78.

12 O. Petrova, Functioning of the ethnic-artistic traditions in professional fine art (based on the materials of national schools of the 60s and 80s, DSc diss., Institute of Philosophy of National Academy of Sciences of Ukraine, 1993; O.N. Petrova, Stylization or materialization of traditions? "Tvorchestvo", 1986/6, pp. 14-16; O. Petrova, Art criticism reflections, Publishing House of Kyiv-Mohyla Academy, Kyiv 2004.

13 P. Sztabińska-Kałowska, Sztuka w świetle..., op. cit. 
The earliest form of graffiti, the "tag", is the most concise piece of information conveyed by the simplest artistic means and very quickly, since such inscriptions are unsanctioned. Consequently, the danger connected with their implementation is the neglect of artistic perfection. The only piece of information that tags convey is the evidence of the writer's presence in as many places as possible, preferably those which are hard to reach. Similar information is also conveyed by inscriptions in the "bombing" technique, with the difference that the tags are applied linearly and bombing is contoured in one or two colours. In contrast to tagging and bombing, the "piece" (masterpiece) testifies to the author's mastery as a street art artist, even though it also mainly contains information on the author, i.e. on their skill of font composition, balance and consistent style of the letters, colour, occurrence of characters as an addition to the font, inscription of the composition into the plane of the wall, proportionality of the font and characters, etc. It is precisely using these criteria that sketches, i.e. works drawn on paper, are evaluated. Almost all types of graffiti report the same thing - that an artist was there and left a message about it, but the difference lies in the completeness of this message.

In general, the way of communicating the characteristics of street art, particularly graffiti, is fundamentally different than in the case of traditional static art in museums, since, from the very beginning, street art has not been elitist art, but art for the masses. Besides, the principal feature of street art is that it is open to feedback and dialogue. Artworks in museums provide a simple overview of exhibits for visitors. However, street artworks make impact through active free dialogue when the art community is steadily transforming and expanding, while requiring no diploma of professional education from new participants. The informational message is produced as follows: the emergence of a new painting as a testament of the author and a nickname as a source of information - a viewing of the picture by the public - the opportunity to find information about the artist on the Internet, using his or her nickname - artists making personal contact through joint drawing. So, street art is not a static way of delivering information; it is a modern means of communication in the context of globalisation, an easy way to get acquainted with an interesting interlocutor and the ability to create a joint art product together.

Based on the methods of exerting influence on the development of an architectural environment, it is possible to divide graffiti art methods into the following groups:

1) stylised font compositions (stylisation of wall calligraphy);

2) graphic compositions (letters or abstract images) on a plane (on external and internal surfaces); large-scale compositions on external surfaces and compositions adjusted to the scale of a specific internal envi- 
ronment on internal surfaces (in this case, drawing is often regarded without any reference to the style of space);

3) stylised comics or realistic images;

4) stylised characters.

The advantages of these methods of shaping the architectural environment are as follows:

- paint is easily applied to almost any surface (ease of design);

- the time of drawing is reduced to days or even hours (speed of work);

- the original drawing fades much more slowly than glued wallpaper or murals and lasts for a long time (durability);

- the works are characterized by specific aesthetics and originality.

Works of muralism use other means to convey an informational message. Muralism is also considered as one of the varieties of street art on facades, in interiors and even on carriageways. Unlike graffiti, which reports on the personality of an artist, murals always report on some kind of events or subject matter and, in their figurative methods, they are closest to monumental art. Murals contribute to the transformation of an urban environment or architecture. However, they do not use architectural and construction means, but artistic techniques, including 3D visualization. Most murals are examples of legally performed large-scale monumental art. If you analyse the kind of information that is conveyed through murals, it may be a narrative, deprived of any political connotation, about the beauty of the landscape, natural phenomena, the world of nature, folk traditions, interpretation of fragments of famous paintings of the past, all in aerosol technology, etc.

Artistic methods of conveying information can be different in this case - it can be realism (most made-to-order murals are executed realistically and this determines their comprehensibility to the general public), historical citation (generating analogies with famous paintings of the past by representing their fragments or a similar manner of execution and composition by analogy), abstractionism and surrealism (hypertrophy and conventionality are emphasised, the content of the story is often understood only by the artist and incomprehensible to the general public without additional explanation), avant-gardism (the use of artistic means of image geometrisation, the imagery of poster painting, visual agitation based on avant-garde patterns of the 1920s-1930s, a conscious use of a limited range of colours - white, black, grey, red), 3D - deconstructivism (conscious destruction of a plane through 3D modelling, deprivation of orientation in space by placing volumetric images on planes). Murals can be located on the walls of a building, on a fence, or on the road surface of a carriageway or sidewalk. 


\section{Street art in different countries of the world}

Against the background of the spread of nationally directed plots, murals began to reminisce about the themes of famous paintings. In such cases, an artist reproduces the creative style of the original work as much as possible. There are examples of imitation of fragments of paintings by Dürer, Renaissance artists, Gustav Klimt and Alfonse Maria Mucha. In some cases, the artist preserves the style of the image, but creates his or her own story "in Mucha's style". Some common phenomena used in modern art have been: the use of deliberate destruction of planes, shocking the audience (when the main subjects are catastrophic - natural disasters, volcanic eruptions, etc.), abstractions, fantastic stories that are placed on walls, roads, carriageways and sidewalks. A prominent place among the various currents of street art is occupied by the works of famous Greek writers. In general, the transformation of Athens into the capital of street art was facilitated by Greek law, loyal to the writers, as well as by the economic crisis. Now, a group of famous masters of muralism has emerged in Greece - Alex Martinez, Fikos, Sonke, INO, STMTS, WD and Pavlos Tsakonas. Pavlos Tsakonas tends to use modernised motifs of classical works of fine art. One example is the placement of huge, upside-down hands clasped in prayer, a motif taken from Albrecht Dürer's picture, on the lateral facade of the Vienna Hotel. Another writer, INO, also uses modernised classic images, such as his "System of a Fraud", where two identical images are superimposed, surreal images of an office worker in a business suit and a Spartan helmet, or an ominous arachnid creature, aimed at the human eye. The same ominous surrealism is present in the paintings of the Indonesian artist WD, where a modern guy with the head of a one-eyed fish-like creature with tentacles, wearing a T-shirt and shorts, is holding a Molotov cocktail. Hypertrophic graphic images of women with closed eyes and long hair are reminiscent of Picasso's works and "The Scream" by the Norwegian artist Edvard Munch.

The artist Fikos is considered a supporter of Byzantine painting, so his graffiti works in the Colonos district of Athens resemble Byzantine paintings in terms of images and colours, with their combination of ancient Greek mythology and Christian symbolism.

Over the past decades, Ukrainian artists have found their place among the global branches of street art. In Ukraine, after the Revolution of Dignity, a fashion for political murals depicting national figures, historical events, national symbols, Maidan events, allegories on the occupation of Crimea and events in the East of Ukraine has spread. Unfortunately, the massive spread of the fashion for murals has led to a violation of the stylistic unity of the environment and picturesque images which exist independently, even if they are qualitatively 
executed. One such example is the image of a stylised Cossack - a simultaneous embodiment of the cultures of Ukraine and Brazil, placed on the house on 6 Spaska Street in Kyiv (Fig. 1). The problem is that the former apartment building was erected in the style of rationalist Secession with decorative elements, while the mural is made in an avant-garde manner and depicts a Ukrainian Cossack whose face is being painted with traditional Brazilian ornaments by Aboriginal hands. This image aims to express the idea of Ukrainian-Brazilian friendship and would serve the purpose on a corresponding modern facade. However, it has nothing to do with either the general stylistics of Spaska Street, or the design of the house itself.

Such an antagonism between architecture and street art on facades is not unique to Ukraine, however. Another illustrative example are the wall paintings on the 13th-century Scottish Kelburn Castle by a team of Brazilian and Scottish graffiti artists. This avant-garde project was unofficially called "a bridge between the cultures" and contributed to an increase in the number of visitors to this architectural monument, but it precisely embodies the antagonism between information conveyed by the architecture and the decor on its walls.

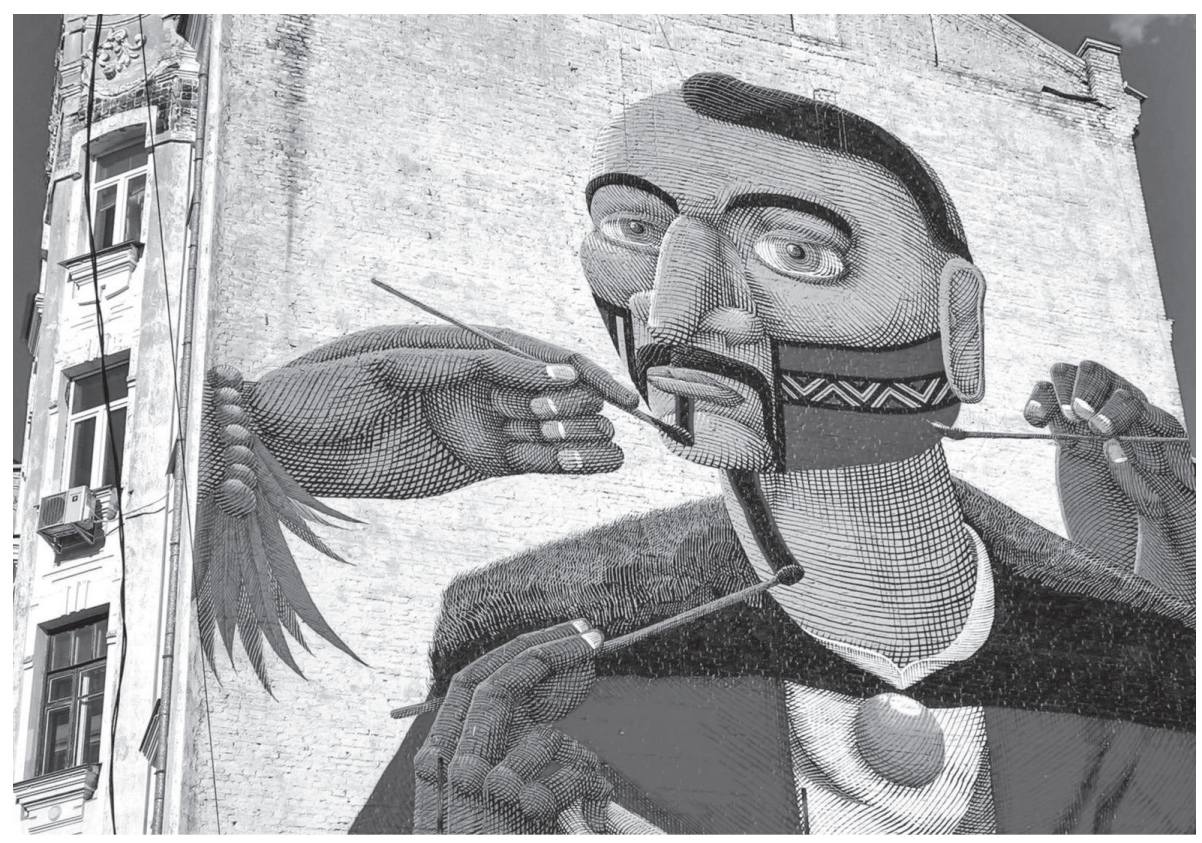

Fig. 1. The Ukrainian-Brazilian Cossack on the facade of the house on 6 Spaska Street in Kyiv. Artist: Francisco Rodrigues da Silva (Nunca) from Brazil, 2015. Photo by O. Ivashko. 
Most frequently, mural artworks decorate the blind ends of facades. However, this creates particular problems which are illustrated by political murals on the houses of Kyiv and other cities of Ukraine, where either the architectural style or the environment are not taken into account. Thus, the images exist in isolation from architecture and urban space, fulfilling the role of ideological posters of the 1920s.

Another movement has produced avant-garde surrealistic murals and a lot of them can be seen in Lodz. To make a comparison with murals in Kyiv, the authors have chosen a famous installation with a bird created by an artist from Portugal (Fig. 2). This project was implemented within the framework of the Energia Miasta Festival, whose organisers deliberately invited an artist who uses the installation technique, thereby complicating the traditional aerosol techniques of street art. By applying elements of urban garbage in his compositions, the artist draws the attention of the general public to the destruction of the natural environment by humankind and the rising number of landfill sites.

Despite the originality of the idea and the manner in which works of street art are performed in Lodz, the same contradiction between the building and

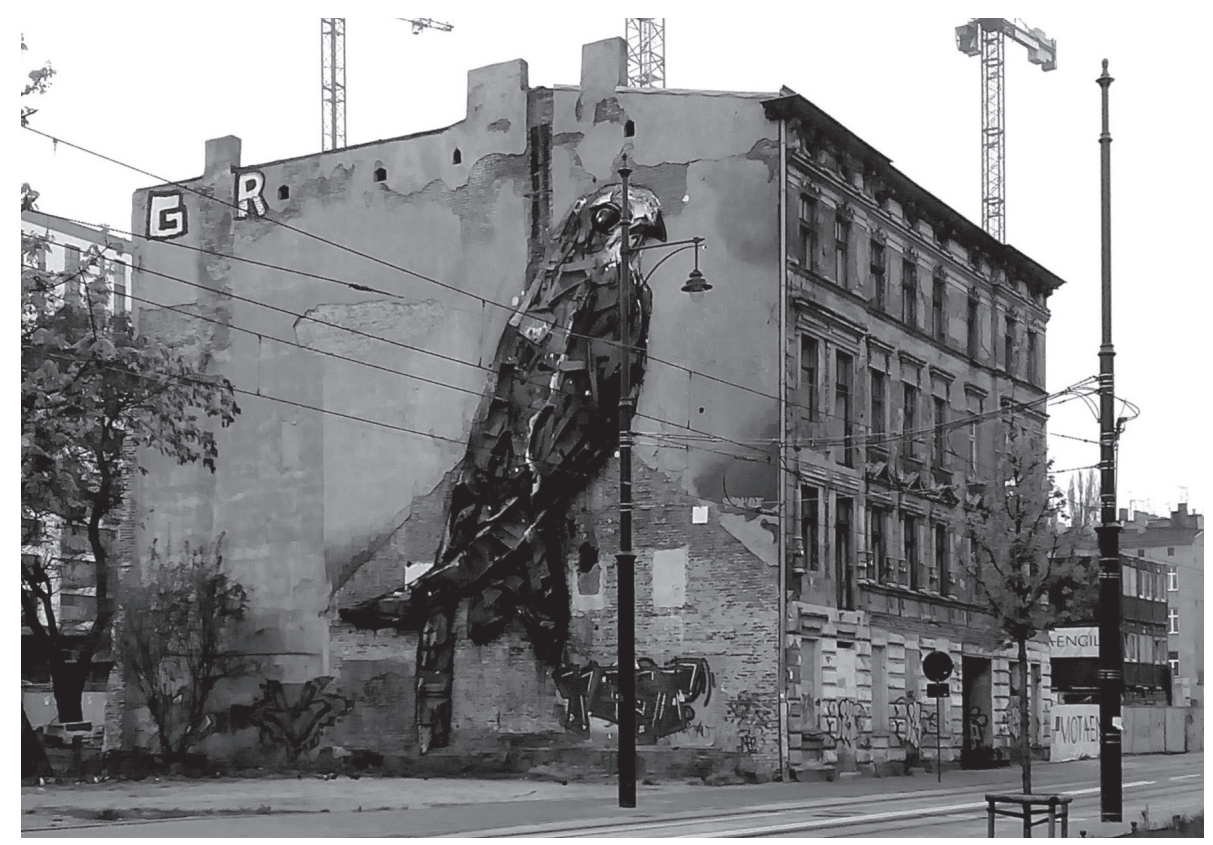

Fig. 2. A mural made from car parts with the image of a bird, Kilińskiego Street in Lodz. Artist: Bordalo II from Portugal, 2015. Photo by O. Ivashko. 
mural or installation styles is also characteristic for some of them. It can be seen in the case of the installation with the bird, which also essentially acts as a propaganda poster for the conservation of nature, animals and birds. However, it exists independently of the historicist architecture of the house.

And here we are directly faced with a difficult dilemma: when do murals and installations enrich the architectural environment, and when do they destroy it? This problem is especially acute when murals appear on every empty front facade in central city districts and then begin to subconsciously irritate the public, which is clearly illustrated by Kyiv. At first, murals that spontaneously spread in the city were admirable, because inhabitants perceived them as opposing the faceless architecture of the Soviet era. Later, however, when their number began to grow, architects and urban planners began to pay attention to how they lead to the destruction of a holistic urban environment. Moreover, a lack of the unanimity of perception of political murals using the images of hetman Pavlo Skoropadskyi, the first president Mykhailo Hrushevskyi and other national figures began to be apparent, which resulted in the murals being repeatedly damaged by vandals.

Given the conflicts that arise when murals or installations are combined with architecture, it is worth mentioning the successful combination of mosaic or pictorial paintings with architecture in earlier styles, e.g. historicism and Secession, where the artistic element acted as a subtle addition to the stylistic facade solution and performed the role of supergraphics (Figs. 3, 4). At the same time, it was in the art of Secession that the theme of the subconscious and abstract was first embodied most massively and intensively. It subsequently developed in other fields of art and is being widely used in modern street art. The art critic O. Petrova paid attention to the oriental philosophical origins of this specificity of Secession, since they determined the figuratively informative form of messages carried by Secession artworks:

"Given the philosophy of art, the Secession style clearly illustrates the position of the "psychology of the unconscious" ... This concept was, to some extent, a kind of "new life" for the philosophical revelations of Taoism, grafted onto the branch of European science. Tao was perceived by the founders of psychoanalysis as one of the forms of personification of the unconscious ... Theory Ch'an emphasizes the significance of spiritual "insight". It captures the instant that is stopped by artistic means, the most creative movement - instant represents eternity." 14

O. Petrova's view on assessing the art of Secession, not according to the socio-economic basis of style, stylistic features, symbolism and philosophical

14 O. Petrova, Art criticism reflections, op. cit., p. 10. 
colouring, but from the point of view of the "philosophy of the unconscious", helps us evaluate the works of street art that cannot be evaluated only with the help of rational criteria. One cannot disagree with the artist that "given the previous history of European styles, it was in Secession for the first time that ... the program included the "phenomenon of misunderstanding", ... the freedom of "unrecognized" - a lack of formality opens up space for heuristic insights, for penetrating beyond the physical "I" ...

The artistic method built on the primacy of intuition, anticipation and touch of secrecy in the process of meditative hallucinatory vision is the discovery of artists of the modern Secession style." 15

The characteristics given to Secession by O. Petrova can also be applied to many "subconscious" plots of street art and muralism. Therefore, some branches of street art, such as postmodernism, can be considered, to some extent, to have "grown" based on the art of Secession: "Secession was an exotic plant of European culture on the eve of changing its aesthetic coordinates. From the moment of its birth, it dangerously balanced on the verge of a conceptualformalized sphere and, through the looking glass, outlined the foundations of the avant-garde in the early twentieth century ..., opened the epoch of "broken consciousness" which in the 20th century's visualization ... ended with the destructiveness of postmodernism." 16

Recognizing the continuity of the methods of conveying information used in the art of Secession and murals, using subconscious perception or allegories, it is worth noting continuity in the application of folklore motifs which were widely used in Ukrainian national romanticism (a Ukrainian equivalent of the Polish folk "Zakopane style"). O. Petrova stated: "The interest of professional artists in ethnic culture is intensified in periods marked by a prevailing crisis (in a given historical period) and, accordingly, the search for new aesthetic-philosophical, as well as spatial-plastic concepts." 17

Here we come close to evaluating the aesthetic interaction of street art, architecture and space, based on the fact that architecture and urban environment are not constant, and develop over time, and that architecture can be evaluated from the standpoint of artistic perfection. In this regard, we should give the general characteristics of architecture formulated by Paulina Sztabinska-Kałowska, emphasizing the appearance of signs of performance as development and transformation in time in modern architecture: "An example is the performative concept of architecture, taking into account not only the finished building, but also the process of its creation, gradual changes the concept has

15 Ibidem, p. 12.

16 Ibidem 12(3), p. 13.

17 Ibidem 12(3), p. 13. 


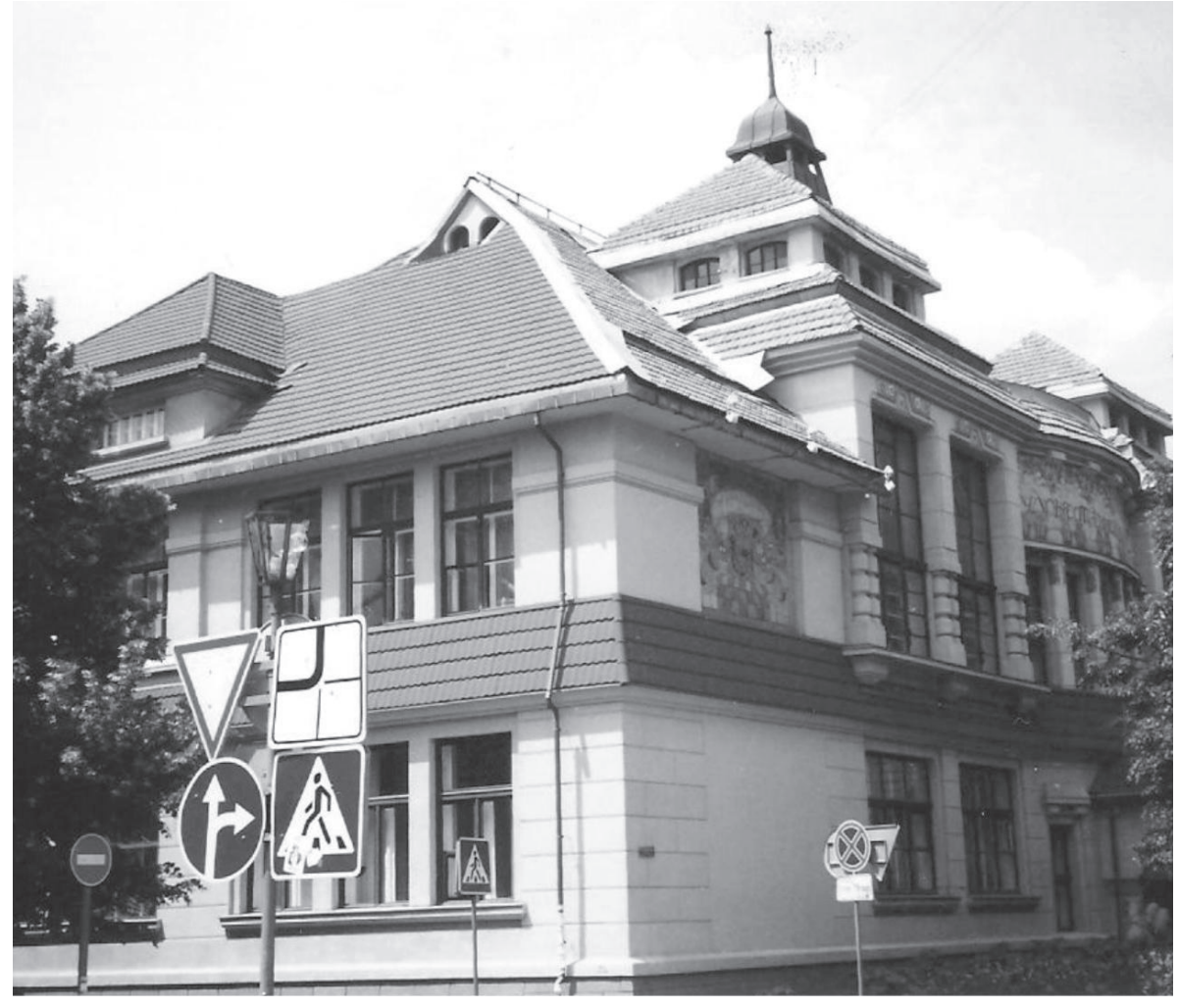

Fig. 3. Ceramic decor on the facade of the Art School in the style of Ukrainian national romanticism on 8 Chervonopraporna Street, Kharkiv (1911-1913, Arch. K.M. Zhukov, M.F. Piskunov). Photo by Yu. Ivashko.

undergone at the stage of architectural design, as well as the following stages of changes that occur during implementation and modifications introduced after completion, related to, for example, a change in function, partial destruction and reconstruction, and the like. From this point of view, both are interesting drawings made with the help of traditional tools and computer modelling taking into account the stages of transformation. Unlike the old concept of an architectural work, when a particular state of the building was considered canonical and the changes were the result of random events that violate the idea of the architect, it is believed that the existence of a building is a kind of idea that occurs in time, where each stage demonstrates a certain stage of "performance."18 


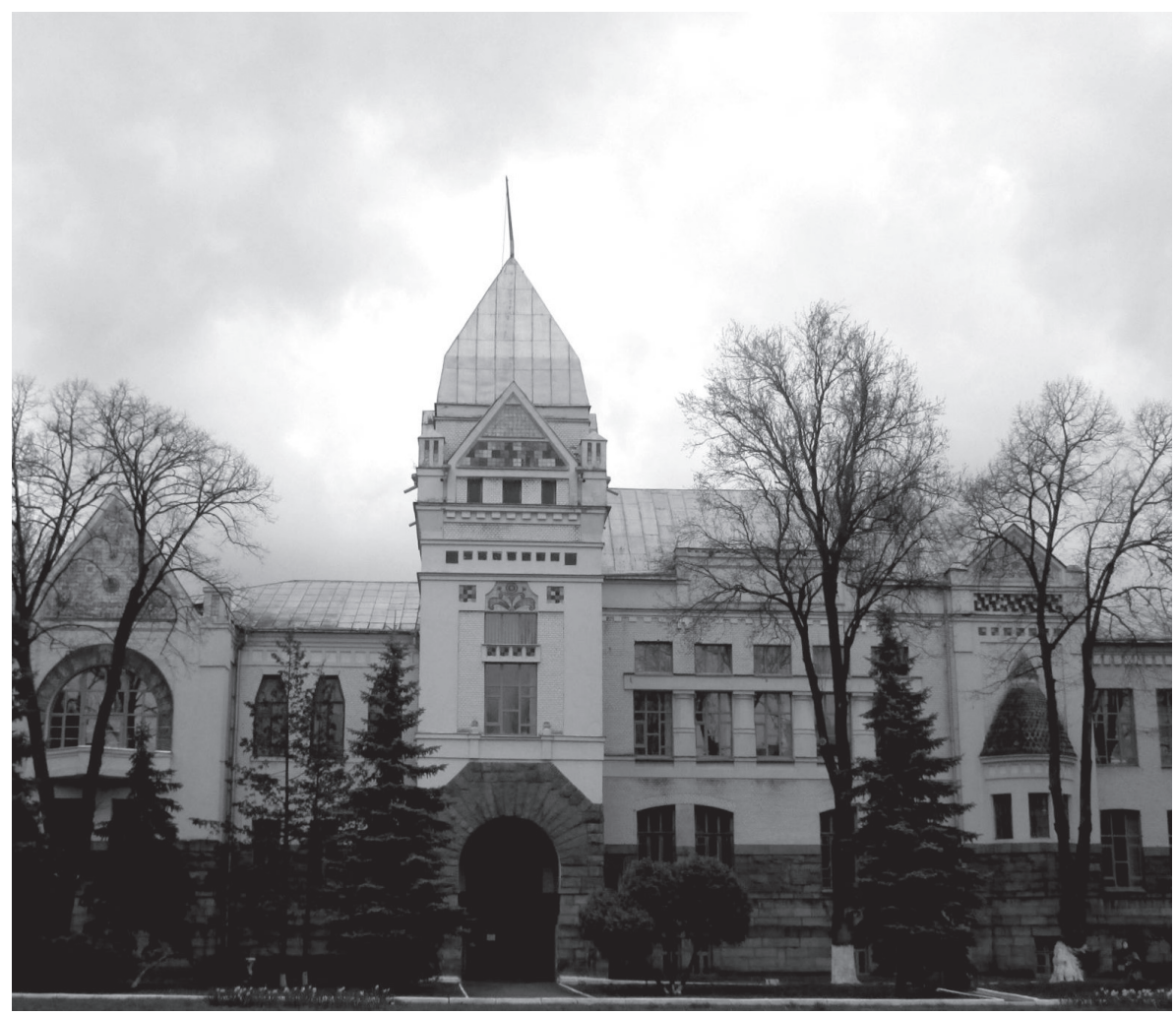

Fig. 4. Decorative panels on the facade of the building of the former Chernihiv branch of the Noble and Peasant Land Bank in the style of northern national romanticism. (1910-1913, architect A.I. von Hohen). Photo by Yu. Ivashko

Regarding Ukrainian street art, O. Petrova poses a relevant question in her monograph "Art criticism reflections" 19 which is on the verge of classical aesthetics and art criticism, and represents the philosophy of modern Ukrainian art. Namely, she focuses on what defines the term "contemporary art" and what criteria define this concept - how long it takes an artist to make a "spiritual product" and samples of artistic evaluation. The author considers it appropriate to "narrow the scope of the term "contemporary art" to relate only to those phenomena that open up fundamentally new philosophical models, paths, directions or stylistic revelations." ${ }^{20}$ The authors intentionally do not

19 Ibidem.

20 Ibidem, p. 34. 
give the final answer to which works of street art should be specifically attributed to art, the art of modernity, thereby leaving room for discussion.

In our opinion, street art is also associated with the art of postmodernism, also based on the search for new ideals. The words which O. Petrova uses to characterize the artistic postmodernism of Ukraine can be attributed to street art: "The generation of postmodernists grew up in the atmosphere of the absurdity of modern life. Over the past ten years, there have been feelings of non-stickiness and a lack of established values. Everything is wrong ... What will happen tomorrow? The secrecy of perspectives in life in creativity gives rise to atypical (subjective) reactions to light: games, clowning, carnivalization of art, as well as the position of tragic plots ... sadistic intonations ... and many other things that are shocking for the viewer." ${ }^{21}$ Today, muralism offers great opportunities for a radical transformation of architectural space exclusively by graphic-pictorial techniques, without the use of expensive building materials and structures. In developed countries, muralism is turning from spontaneous street art into a characteristic feature of cities and, in many cases, into a means of advertising, performance and customer acquisition. Formerly persecuted artists who furtively painted graffiti on the streets as a sign of protest have now become well-known writers who are gradually turning into wealthy professionals and receiving prestigious orders from city administrations and private firms. Works of modern high-quality muralism are starting to be expensive, which consequently encourages writers to improve.

In order to objectively assess the positive or negative impact of street art on urban space, it is necessary to draw an analogy with the works of monumental art of the Soviet period which were also carriers of certain information. In Soviet times, there was a special kind of a comprehensive art program for the decoration of buildings with pieces of monumental propaganda. It provided for the holistic design of particular areas in a specific style, beginning with an open discussion at the draft step. Unfortunately, this process is uncontrollable in Ukraine nowadays. It poses a serious threat to historical areas and protection zones around the monuments of architectural heritage. It is in this case that we can talk about a radical transformation of spontaneous street art into an element of the modern aesthetics of the urban environment, about the argumentative possibilities of the aestheticisation of this subculture and the need to take into account the environmental approach. It requires considering murals precisely from the perspective of designing the architectural environment, with the involvement of specialists - architects and urban planners, especially because, unfortunately, there are no architects among writers, since architects think in spatial categories.

21 Ibidem, p. 373. 
The state of development of modern street art opens up fundamentally new opportunities for transforming architectural space exclusively by graphic and pictorial methods of an artistic narrative. In our opinion, the use of street art, especially muralism, seems appropriate when designing the blind end facades of buildings. It allows us to diversify the same type of facades and to provide a picture of the integrity of urban development in cases where the image on the facades corresponds to one idea and is stylistically close. Besides, the effect of a particular performance is hidden in muralism, especially in 3D murals. In our opinion, such murals are most suitable in amusement parks, recreation places, playgrounds, etc., while their location on carriageways is unjustified, since it may lead to dangerous situations on the roads.

\section{Conclusions}

The question of the narrative of street art is debatable and needs further study. As mentioned above, street art as natural art is self-sufficient and does not require reinforcement or supplementation by other artistic means. The main narrative of street art works is through certain images. Namely, spontaneous street art aims to intervene in urban spaces - either to mark "I was here", or to leave a certain message, include a reaction to a political event, a protest, or to take place just like that, without a specific goal. When street art evolves from elemental art, whose primary goal is to communicate certain information placed on external surfaces to many people, and is transferred to a festival or gallery space, the nature of its narrative changes somewhat because it is primarily influenced by the commercial component. This leads to strengthening street art by other artistic means which aim to attract as many visitors as possible. And this is the main difference between spontaneous street art and street art on a commercial basis, which actually loses the features of spontaneous "street" art and turns into just modern art. The same applies to muralism, when commissioned works actually cease to be street art and convey a certain narrative already defined by the customer.

Today in Ukraine, street art performs several functions that differ when it comes to legal and illegal art. As for legal art, murals perform the ideological function of a propaganda poster, with the difference that such a poster provides temporary agitation, while a mural is permanent. They also have an aesthetic function thanks to the image of landscapes or apolitical abstractions. The ideological function is dominant and serves several purposes: nurturing a national idea in the society (portraying prominent figures of the Ukrainian state, national plots, scenes from folk legends and fairy tales), promoting patriotism (plots on the theme of the occupation of Crimea, the war in Donbas, Maidan events), 
depicting the struggle for a clean environment and the preservation of nature (stories with animals, birds and picturesque landscapes), referring to friendship between the peoples of the world, etc. Illegal art is apolitical, although in times of crisis it also undergoes political and ideological influences. Dominant information comes from illegal street art - graffiti and murals. There is information on the artist's personality and skills. The phenomenon of street art in an urban environment should be assessed by two criteria - spatiality (environmental compliance) and artistic skill (quality of performance).

A problem arises when a street artist thinks in the category of one separate plane, one object and not an integral environment, when he or she does not feel the spatial architectural and urban context in which he or she works. However, people perceive the space of a street as a whole. Therefore, a creator's drawing must be integrated with the space.

It shows particular administrative disorder in the process of spontaneous distribution of murals without taking into account the spatial perspective, when only a small percentage of murals are suitable for the urban environment, despite the high quality of the artistic skills of their authors. This indicates that a work, even if skilfully executed, is negatively perceived by people who, due to its antagonism with space, feel a dissonance within the architectural environment.

Unfortunately, high-quality professionally executed paintings are often in dissonance with the environment. So, we can talk about conflict between artistic narration and the established urban environment. This is the reason for conducting further research on the specifics of the narration of street art, including the negative that constitutes a feature of this type of art. The fact is that street artists did not initially aim to convey a message that would have a positive effect (in contrast, even paintings depicting disasters or tragic events can have a positive effect on the viewer due to the skill of execution or the power of expression of emotions). The narrative of street art and of this type of art included in galleries is fundamentally different.

\section{BIBLIOGRAPHY:}

Bezklubenko Serhii (1997) Art and power. Grumpy spouses?, "Viche” No. 8, pp. 125-134.

Bezklubenko Serhii (2000) Essays on the general theory of art. I. What is art?, "Bulletin of KNUKIM". "Series in Arts" Kyiv, Vol. 3, pp. 4-19.

Bezklubenko Serhii (2001) Essays on the general theory of art. II. The origin of art, "Bulletin of KNUKIM". "Series in Arts" Kyiv, Vol. 4, pp. 4-33.

Bezklubenko Serhii (2001) Essays on the general theory of art. III. The formation of art form. What is "artistic", "Bulletin of KNUKIM". "Series in Arts". Kyiv, Vol. 6, pp. 16-26. 
Bezklubenko Serhii (2002) Essays on the general theory of art. V. Formation of the arts. Ch. I. Applied art; Ch. II. Building art, "Bulletin of KNUKIM". "Series in Arts". Kyiv, Vol. 7, pp. 10-20.

Bezklubenko Serhii (2002) Essays on the general theory of art. Culture and art in the modern world: scientific issues, "Bulletin of KNUKIM". Kyiv, Vol. 7, pp. 164-168.

Bezklubenko Serhii (2003) Essays on the general theory of art. VI. The formation of the arts. Chapter 3. Painting; Chapter 4. Musical art, "Bulletin of KNUKIM". "Series in Arts". Kyiv, Vol. 8, pp. 12-29.

Iwaszko Oleksandr (2018) Społeczna Przyroda Nowych Artystycznych kierunków w Miejskim Środowisku. Przestrzeń / Urbanistyka / Architektura, 2/2018, pp. 167-176.

Ivashko O. (2019) The issues of conservation and revitalization of the monuments of industrial architecture. "Wiadomości Konserwatorskie - Journal of Heritage Conservation" / 58/2019 pp. 113-117.

Ivashko Yulia (2009) Features of the use of natural motifs in modern architecture. "Bulletin of Lviv Polytechnic National University”, No. 656, pp. 38-43.

Ivashko Yulia (2010) The influence of Japanese art on the art and architecture of Europe in the late nineteenth and early twentieth centuries, "Linguistic and Conceptual Views of the World" Vol. 28, pp. 250-254.

Ivashko Yulia (2011) The influence of Buddhism and Shintoism on the development of religious and philosophical ideas in Europe in the nineteenth and early twentieth centuries, "Linguistic and Conceptual Views of the World” Vol. 28, pp. 277-280.

Ivashko Yulia, Kuzmenko Tetiana, Li Shuan, Chang Peng (2019). The influence of the natural environment on the transformation of architectural style, "Landscape architecture and Art". 2019, vol. 8, No 8, pp. 101-108.

Kulikov Petro, Dyomin Mykola, Chernyshev Denys, Kuśnierz-Krupa Dominika, Krupa Michał. (2019). The issues of preservation and revitalization of residential, public and industrial buildings from the second half of the 19th and early 20th centuries in Kyiv and Krakow, "Wiadomości Konserwatorskie - Journal of Heritage Conservation”, 60, 2019, pp. 140-146.

Shylo Oleksandr, Ivashko Oleksandr (2016) Monumental art and street art in modern urban space "Scientific Herald of Construction" No. 2 (84), pp. 74-78.

Petrova Olha (1993) Functioning of the ethnic-artistic traditions in professional fine art (based on the materials of national schools of the 60s and 80s) DSc diss., Institut of Phylosophy of National Academy of Sciences of Ukraine.

Petrova Olha (1986) Stylization or materialization of traditions? "Tvorchestvo", No.6, pp. 14-16.

Petrova Olha (2004) Art criticism reflections. Kyiv: Publishing House of Kyiv-Mohyla Academy.

Ortodox Poltavshchyna (composed by A. Dmytrenko, L. Onischuk, V. Shulyk) (2008), Poltava: ASMI. 
Sztabiński Grzegorz (2019). Why Do We Need the Term "Art"? "Art Inquiry. References sur les arts”, volume XXI (XXX), pp. 19-35.

Sztabińska-Kałowska Paulina (2019) How does performance affect the understanding of 'Art'. "Art Inquiry. References sur les arts", volume XXI (XXX), pp. 111-127.

Sztabińska-Kałowska Paulina (2019). Sztuka w świetle zwrotu performatywnego, manuscript.

\section{SZTUKA ULICZNA: PRZEKAZ ARTYSTYCZNY W NOWO- CZESNYM ŚRODOWISKU MIEJSKIM (streszczenie)}

Przez cały czas istnienia ludzkości formułowano odpowiednie kryteria dla środków informacyjnych i przedmiotu dzieł sztuki. Wiek XX charakteryzował się fundamentalną reinterpretacją sensowności i sposobu przekazu informacyjnego sztuki, która utraciła dominującą rolę w niektórych zakresach - przekazywania ideałów estetycznych, edukacji społeczeństwa w duchu harmonii i piękna - wprowadzając cechy moralne z wykorzystaniem środków artystycznych, pewne treści ideologiczne itp. Sztuka uliczna kontrastowała ze sztuką tradycyjną i wielowiekowymi środkami artystycznymi w sposobie dostarczania pewnych informacji, a główną przyczyną jej powstania były problemy społeczne okresu powojennego w biednych dzielnicach Nowego Yorku. W warunkach bezrobocia, ogólnej depresji i ubóstwa, młodzi ludzie wymyślili nowe rozrywki wykorzystując wszystko, co było w pobliżu. A potem, kilka lat później, ten trend objął niemal wszystkie kraje świata - zarówno biedne, jak i bogate. W ten sposób okres powojenny przyniósł deskorolki, rap, graffiti i street art w obecnej formie.

Stopniowo znaczenie sztuki ulicznej pogłębiło się i poszerzyło: oprócz wyrażania siebie i protestów społecznych, wśród aktualnych celów pojawił się także indywidualny sprzeciw wobec postępującej globalizacji, pojawiły się implikacje polityczne, które, na przykład, zdecydowanie charakteryzują graffiti i malowidła ścienne Rewolucji Godności na Ukrainie. W trakcie swojego rozwoju legalna sztuka uliczna oddzieliła się od nielegalnej, czysto amatorskiej, spontanicznej. Pojawili się także artyści, którzy zaczęli uprawiać „komercyjną sztukę uliczną”, którą lepiej byłoby nazwać sztuką miejską lub po prostu nowoczesną sztuka, ponieważ nie jest już tworzona w warunkach ulicznych i znajduje się coraz bardziej pod prerogatywą galerii sztuki i prywatnych klientów. Postawa innych artystów, którzy nie uważają swojej pracy za komercję, jest często nieco niejednoznaczna, ponieważ promują oni sztukę poza polityką i handlem, uprawiając „sztukę dla sztuki”. Ciekawym zjawiskiem należącym do tego porządku w sztuce ulicznej są realizacje młodych artystów bez dostępu do zewnętrznego finansowania, które stały się swoistym „klastrem artystycznym”, czy raczej „klastrem kreatywnym”. Ich pojawienie się było możliwe ze względu na dostępność znacznej liczby niedziałających przedsiębiorstw przemysłowych, w których artyści wynajmowali puste pomieszczenia za symboliczną opłatą.

Osobliwość sztuki ulicznej polega na tworzeniu narracji będącej interwencją w miejski obszar. W tym przypadku każdy artysta ma swój cel: przekazać wiadomość, upamiętnić siebie, zareagować na polityczne zdarzenie, wyrazić protest itd. W przypadku, gdy sztuka uliczna ze spontanicznej staje sztuką na festiwalu czy w przestrzeni galerii, może uzyskać transmedialny charakter i być dopełniona tańcami, performansami, muzyką.

Słowa kluczowe: sztuka uliczna, graffiti, muralizm, kryterium artystycznej oceny, narracje. 
Dyomin Mykola - Doctor of Science (Architecture) (1988), Professor (1990), Honored Architect of Ukraine (1997), Corresponding Member of the National Ukrainian Academy of Arts (2001), Professor of the International Academy of Architecture (1992), full member, Vice-President of the Ukrainian Academy of Architecture. In 1975-1986 - Head of the Department of the General Plan of Kyiv; 1988-2002 Director of the Research Institute of Theory and History of Architecture and Urban Planning.

From 1986 to the present, Head of the Department of Urban Construction of Kyiv National University of Construction and Architecture.

Author of more than 60 significant architectural and urban projects, and more than 300 scientific articles. Scientific interests and fields of scientific activity: architecture, urban studies, art theory.

1. Dyomin, M.M., Orlenko, M.I. (2017). The systematic approach to monuments and restoration activities. Urban planning and territorial planning: Scientific and technical collection, Osietrin, M.M. (Ed.). Kyiv, KNUCA. Issue 65, pp. 21-32.

2. Dyomin Mykola, Ivashko Oleksandr. The systematic approach to the revitalization of historical fortifications and industrial enterprises under art clusters, Chełm - Lviv, 2018. No. 10. pp. 30-33.

3. Dyomin Mykola, Ivashko Yulia, Rezga Kouider, Mosques of Algeria: Architectural and Urban Aspects, Kyiv, 2019, p. 192.

4. Dyomin Mykola, Ivashko Oleksandr, Street Art as a new Phenomenon of Art - a Means of Centrification of the Urban Environment, "Art Inquiry. References sur les arts", volume XXI (XXX), pp. 129-148.

Ivashko Oleksandr - Master of Science in Architecture, a post-graduate student. Scientific interests and fields of scientific activity: street art, contemporary art, art clusters.

1. Ivashko, O.D., Orlenko M.I. Art-Clusters as a New Type of Buildings: the Specificity of the Spatial Solution and the Features of Restoration during the Redevelopment Process (The Experience of Poland). / Środowisko Mieszkaniowe (Housing environment), Kraków, 2017. No. 21. pp. 109-115.

2. Iwaszko O. Społeczna Przyroda Nowych Artystycznych Kierunków w Miejskim Środowisku, "Przestrzeń/Urbanistyka/Architektura" 2/2018, pp. 167-176.

3. Ivashko, O., Perehuda, Ye. Street art as a factor of cultural development and an element of symbolic politics in post-revolutionary Ukraine. Stosunki międzykulturowe. Tom 1. Strategie bezpieczeństwa i komunikacji we wspótczesnym świecie, Zielona Góra, 2016, pp. 155-174.

4. Ivashko O. Możliwości użycia sztuki ulicznej we wspótczesnym dostosowaniu zamków i twierdz. Current issues in research, conservation and restoration of historic fortifications, Chełm-Lviv, 2016, pp. 86-90.

5. Dyomin Mykola, Ivashko Oleksandr. Street Art as a new Phenomenon of Art a Means of Centrification of the Urban Environment, "Art Inquiry. References sur les arts”, volume XXI (XXX), pp. 129-148. 